\title{
An outbreak of acute Chagas's disease in the Sào Francisco Valley region of Bahia, Brazil : triatomine vectors and animal reservoirs of Trypanosoma cruzi
}

\author{
T. V. BARRETT * \\ Dept. of Entomology, London School of Hygiene and Tropical Medicine, Keppel Street, London WCIE $\% H T$ \\ R. HoFF ${ }^{\star}$, K. E. MOTT* \\ Dept. of Tropical Public Health, Harvard School of Public Health, 66.5 Huntington Ave., Boston, MA. (2:11.), \\ $U S A$
}

F. Guedes

Faculdade de Medicina, Universidade Federal da Bahia, Salvador, Bahia, Brazil

AND

I. A. SHERLOCK

Nucleo de Pesquisas da Bahia, Fundação Oswaldo Cruz, Salvador, Bahia, Brazil

\begin{abstract}
Summary
Following reports of an unusually high incidence of acute Chagas's disease and the appearance of large numbers of Triatoma infestans in the southwestern region of the State of Bahia, triatomine bugs (Hemiptera: Reduviidae) and domestic animals in one of the affected communities were surveyed and examined for infection with Trypanosoma cruzi. Triatoma infestans was prevalent in houses and was also found in peridomestic habitats. $T$. sordida and $T$. pseudomaculata occupied peridomestic and sylvatic habitats and $T$. brasiliensis was found only among rocks far from houses. Panstrongylus megistus, formerly present in the region, was not found. Trypanosoma cruzi was detected in $19.5 \%$ of Triatoma infestans, $11.5 \%$ of $T$. sordida, $19 \%$ of dogs, $29^{\circ} \%$ of cats and $100^{\circ} \circ$ of rats examined. A disproportionate number of early instar bugs were infected with Trypanosoma cruzi, suggesting that a rapid increase in the rate of transmission had recently occurred.

The history of the domestic triatomine fauna of the region since 1912 is reviewed, and it is proposed that the relatively recent arrival of Triatoma infestans initiated a domestic cycle linked to peridomestic and sylvatic cycles of Irypanosoma cruzi transmission. Increased human mobility, the use of DDT for malaria control, and drought conditions are considered as factors which might have contributed to the outbreak of human infection.
\end{abstract}

\section{Introduction}

Most epidemiological studies of Chagas's disease have been carried out in regions of stable transmission of Trypanosoma cruzi. Serological evidence suggests that in such regions most of the initial infections are acquired before the age of 20 , often without any evident acute phase of illness (MOTT et al., 1976). During 1975, acute Chagas's disease was diagnosed in eight patients aged seven to 65 years from the administrative district ("municipio") of Riacho de Santana, who had been admitted to the Hospital Professor Edgard Santos of the Federal University of Bahia in Salvador. These patients and their relatives knew of many similar cases and reported that houses in the area had recently become heavily infested with triatomines. This unusual clustering of acute cases, and reports of heavy infestations by Triatoma infestans, prompted us to investigate this outbreak with the aid of the national vector control service (SUCAM).

In this report we describe the distribution of triatomine vectors and reservoir hosts of Trypanosoma cruzi in a rural community in Riacho de Santana. The results of clinical and serological studies and of biochemical characterization of $T$. cruzi from this area will be discussed elsewhere.

The study area

\section{Materials and Methods}

The municipio (administrative district) of Riacho de Santana covers $3708 \mathrm{~km}^{2}$ in the Serra Geral region of the state of Bahia and the urban area is situated $60 \mathrm{~km}$ east of the São Francisco river (Fig. 1). 'The 1970 census recorded a total population of about 30,000 , of whom $87 \%$ were rural residents, and the estimated population in 1976 was 34,000 . The vegetation is predominantly xeromorphic deciduous woodland and scrub ("caatinga") (HUECK, 1960-61). The single rainy season lasts from October to March. During the previous 10 years the mean annual rainfall had been $822 \mathrm{~mm}$. Maximum and minimum temperatures were $39 \cdot 1^{\circ} \mathrm{C}$ and $10^{\circ} \mathrm{C}$, and the average monthly temperature ranged from $22 \cdot 7^{\circ} \mathrm{C}$ to $28 \cdot 9^{\circ} \mathrm{C}$. A drought in 1975 and 1976

*Consultants to the Pan Amcrican Hcalth Organization. 


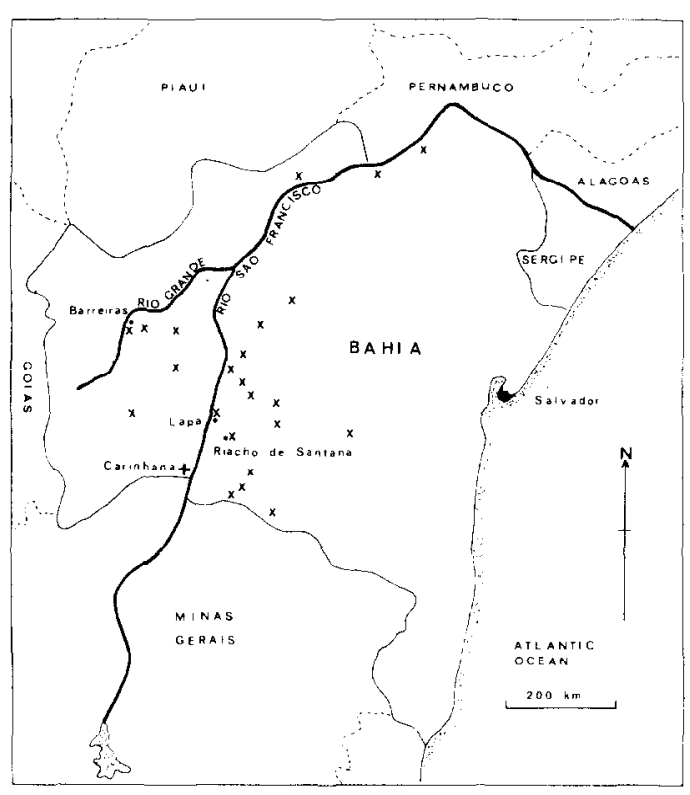

Fig. 1. Bahia and neighbouring states.

- Municipio in Bahia with $T$, infestans in 1956 (based on Dias \& SEREBRENICK, 1958)

$\times$ Municipios in Bahia with $T$, infestans in 1971 (based on SHERLock \& SERAFIM, 1972)

severely affected production of cattle, maize, cotton and beans, on which the economy of the region depends. Commerce has traditionally been linked with the States of São Paulo and Minas Gerais, and many residents have at some time travelled to São Paulo in search of jobs. Until 1950 communications with these states were mainly dependent on the River São Francisco but, since then, traffic has increasingly moved by lorry on new roads connecting the region with Minas Gerais. Traffic is heaviest during August and September, when up to 2000 lorries carrying pilgrims to the town of Bom Jesus da Lapa (indicated as "Lapa" in Fig. 1) pass through Riacho de Santana from the south.

Malaria, formerly an important disease, has been brought under control by spraying houses with DDT, and the spraying programme was still in operation in 1976. In 1969, local physicians diagnosed the first cases of an outbreak of acute Chagas's disease. About 50 cases had been reported in the three years before our visit in March, 1976.

A rural community $9 \mathrm{~km}$ from the town of Riacho de Santana was selected for intensive study. The community comprises the Fazenda (rural area) Barreiro Vermelho and two houses of a neighbouring Fazenda. 'The most recent case of acute Chagas's disease known to us had occurred in this community. With the help of the local staff of SUCAM we prepared a map and took a census: 21 households with 120 residents and their 28 dogs and 35 cats were studied.

Two of the houses were of mud and wattle construction with unplastered walls, while the

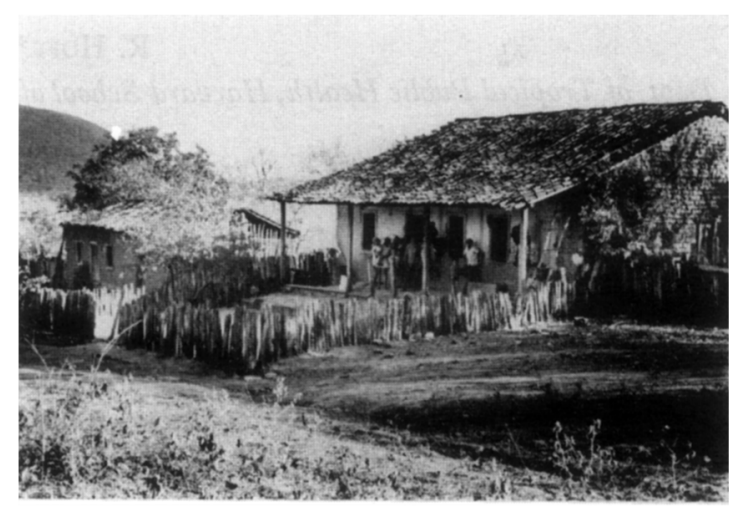

Fig. 2. Houses CEM 21 and CEM 22 in Barreiro Vermelho. Note the crevices between bricks where the wall is unplastered, the maize store behind the houses, and the proximity of the woodland in the background.

remainder were solidly built and had wholly or partially plastered brick walls (Fig. 2). All had tiled roofs. Houses were spaced from 20 to 400 meters apart. A peridomestic area, in most cases enclosed by a wooden fence, usually contained a structure used for storing maize (Fig. 2), a chicken house, loose boards, spare tiles and often a pig-pen. In many cases this peridomestic area was directly adjacent to the surrounding woodland.

\section{Survey of triatomines}

Two assistants searched the inside of each house for $20 \mathrm{~min}$ using torches and forceps while a third searched fence posts, chicken houses and other likely habitats in the peridomestic area. In sylvatic areas remote from houses we searched tree holes, the bark of dead trees, fence posts and outcrops of rock. Rupicoline (rock-inhabiting) triatomines were induced to emerge from their hiding places by the presence of the collectors, who sat quietly and captured the bugs as they approached to feed in full daylight. Captured bugs were placed in plastic pots containing filter paper to absorb the faeces and transported to the laboratory in insulated boxes.

Triatomine eggs were collected from two houses in the town of Riacho de Santana and from two houses and a peridomestic enclosure in Barreiro Vermelho, and examined for evidence of parasitism by microhymenoptera.

\section{Survey of reservoir hosts}

Of the 63 dogs and cats in the study area, 57 were subjected to xenodiagnosis with five fifth-instar 
Table I-Distribution of Triatoma infestans and $T$. sordida in houses and peridomestic areas, and number of bugs infected with Trypanosoma cruzi. Fazenda Barreiro Vermelho, Riacho de Santana, March 1976

\begin{tabular}{|c|c|c|c|c|c|c|c|c|}
\hline \multirow{3}{*}{$\begin{array}{c}\text { CEM } \\
\text { number }\end{array}$} & \multicolumn{4}{|c|}{ Houses } & \multicolumn{4}{|c|}{ Peridomestic Area } \\
\hline & \multicolumn{2}{|c|}{ T. infestans } & \multicolumn{2}{|c|}{ T. sordida } & \multicolumn{2}{|c|}{ T. infestans } & \multicolumn{2}{|c|}{ T. sordida } \\
\hline & total & $\div$ & total & + & total & + & total & $\therefore$ \\
\hline 1 & 14 & 2 & 0 & - & 106 & 23 & 8 & 3 \\
\hline 2 & 11 & 1 & 0 & - & 1 & 0 & 14 & 0 \\
\hline 3 & 2 & 0 & 0 & - & 0 & - & 1 & 0 \\
\hline 4 & 0 & - & 0 & - & 0 & - & 2 & 0 \\
\hline 5 & 39 & 1 & 0 & - & 3 & 1 & 0 & - \\
\hline 10 & 13 & 0 & 0 & - & 0 & - & 4 & 0 \\
\hline 11 & 20 & 0 & 0 & - & 0 & - & 14 & 0 \\
\hline 12 & 2 & 0 & 0 & - & 0 & - & 0 & - \\
\hline 14 & 6 & 3 & 0 & - & 6 & 0 & 0 & - \\
\hline 15 & 6 & 3 & 0 & - & 0 & - & 32 & II \\
\hline $16 \mathrm{cl}$ & 18 & 2 & 0 & - & 0 & - & 0 & - \\
\hline $16 \mathrm{c} 2$ & 4 & 1 & 0 & - & 1 & 0 & 11 & 1 \\
\hline $16 \mathrm{c} 3$ & 5 & 0 & 1 & 0 & l & 0 & 1 & 0 \\
\hline $16 \mathrm{c} 4$ & 13 & 0 & 0 & - & 1 & 0 & 55 & 2 \\
\hline $17 \mathrm{cl}$ & 11 & 2 & 0 & - & 0 & - & 2 & 0 \\
\hline 18 & 3 & 1 & 0 & - & 0 & - & 0 & - \\
\hline 19 & 2 & 0 & 0 & - & 0 & - & 9 & 0 \\
\hline$\star 21$ & 2 & 0 & 0 & - & 0 & - & 0 & - \\
\hline$\star \star 22$ & 28 & 7 & 0 & - & 0 & - & 0 & - \\
\hline$\star 23$ & 0 & - & 0 & - & 0 & - & 0 & - \\
\hline PL $1 \mathrm{cl}$ & 30 & 21 & 0 & - & 0 & - & 0 & - \\
\hline PL 2 & - & - & - & - & 0 & - & 2 & 1 \\
\hline Total & 229 & $44(19 \cdot 2 \%)$ & 1 & 0 & 119 & $24\left(20 \cdot 2 n_{n}\right)$ & 155 & $18\left(11 \cdot 6^{\%}\right)$ \\
\hline
\end{tabular}

+ number positive for $T$. cruzi

* sprayed with BHC several days before sampling

* house abandoned for 3 months before sampling

Table II-Rate of Trypanosoma cruzi infection in Triatoma infestans and in $T$. sordida according to developmental stage of the bugs. Barreiro Vermelho, March 1976

\begin{tabular}{lcccc}
\hline & \multicolumn{2}{c}{ T. infestans } & \multicolumn{2}{c}{ T. sordida } \\
\hline Stage & No. examined & " positive & No. examined & " positive \\
\hline I & 4 & 0 & 33 & 0 \\
II & 10 & $10 \cdot 0$ & 10 & $30 \cdot 0$ \\
III & 23 & $34 \cdot 8$ & 5 & 0 \\
IV & 45 & $15 \cdot 6$ & 15 & $20 \cdot 0$ \\
V & 151 & $21 \cdot 9$ & 32 & $15 \cdot 6$ \\
adult & 115 & $17 \cdot 4$ & 61 & $11 \cdot 5$ \\
Total & 348 & $19 \cdot 8$ & 156 & $11 \cdot 5$ \\
\hline
\end{tabular}

nymphs of Triatoma infestans or Rhodnius prolixus from the colony of the Nucleo de Pesquisas da Bahia. Rats (Rattus rattus) were captured with "Whole Fanily" rat traps (S. Young \& Sons Ltd., Misterton, Somerset, U.K.) that were baited with cheese and bacon and placed near the houses. For parasitological examination the rats were anaesthetized with intraperitoneal pentobarbitone sodium
("Nembutal": May and Baker Ltd.) and subjected to xenodiagnosis with five fifth-instar nymphs of $T$. infestans and five fifth-instar nymphs of $R$. prolixus. At the same time, tail blood from cach rat was examined microscopically for trypanosomes and several drops were inoculated into a fortified NNN blood agar slant with F29 medium as overlay (PAN, 1968). 


\section{Examination of triatomines}

25 to 35 days after feeding, the rectum and posterior midgut of each of the bugs used in xenodiagnosis were dissected into physiological saline solution on a microscope slide. Each slide was scanned using the $10 \times$ objective for 12 to $15 \mathrm{~min}$ or until flagellates were seen. Bugs collected in the survey were examined in the same way.

\section{Triatomines}

\section{Results}

The triatomine species encountered in Riacho de Santana were Triatoma infestans (Klug, 1834), T. sordida (Stal, 1859), T. brasiliensis Neiva, 1911 and $T$. pseudomaculata Correia \& Spinola, 1964.

Table I shows the domestic/peridomestic distribution of the captured bugs and the number infected with Trypanosoma cruzi. Triatoma infestans was found in 19 of the 22 houses examined, including one which had been abandoned by its owners three months previously but in which pigs and chickens were still kept. With the exception of a single adult $T$. sordida, all the bugs found in houses were $T$. infestans.

$T$. sordida was the predominant species in the peridomestic area where it was found mainly in fencing, loose timber and other wooden structures. $T$. infestans was also present in peridomestic habitats, particularly at house CEM1 which differed from the others in having a brick annex to the house. In this annex, 17 of $23(74 \%)$ bugs from a ratinfested storage box and nine of $91(10 \%)$ bugs from a brick wall where chickens roosted were infected with Trypanosoma cruzi.

A single, uninfected adult Triatoma pseudomaculata was found in a chicken house.

Bugs infected with Trypanosoma cruzi were found in $50 \%$ of the houses and $27 \%$ of the peridomestic enclosures. Over-all, 19 to $20 \%$ of Triatoma infestans and $11.5 \%$ of $T$. sordida were infected with Trypanosoma cruzi.

Table II shows the prevalence of $T$. cruzi in Triatoma infestans and $T$. sordida according to the developmental stage of the bugs. In both species, the infection rate was higher in nymphs than in adults and higher in adult females than in adult males ( $T$. infestans females $24.1 \%$, males $11.5 \%$; $T$. sordida females $17 \cdot 6 \%$, males $3 \cdot 7 \%$ ).

In the urban area of Riacho de Santana $32 \%$ of $97 T$. infestans collected from four houses known to be heavily infested were positive for Trypanosoma cruzi.

In the woodland we found seven Triatoma pseudomaculata and one $T$. sordida in treeholes that also contained lizards, feathers, hairs of the primate Callithrix sp. and a rodent nest. One $T$. sordida and one $T$. pseudomaculata were found in fence posts far from houses. 20 individuals of a dark variety of $T$. brasiliensis were captured among boulders of granitic gneiss inhabited by lizards (Tropidurus torquatus and other species) and rock cavies (Kerodon rupestris). None of these sylvatic or rupicoline bugs was infected with Trypanosoma cruzi.

\section{Predators and parasites of triatomines}

None of 795 eggs of $T$. infestans had any signs of parasitism. However, nine of $24 T$. sordida eggs from a peridomestic enclosure in Barreiro Vermelho had exit holes made by parasitoid wasps which, when reared from parasitized eggs were identified as Telenomus fariai Costa Lima, 1927 (Scelionidae). One fifth-instar Triatoma sordida from the same enclosure was parasitized by a mermithid larvathe first time that any triatomine has been found naturally parasitized by a nematode. A high proportion of $T$. brasiliensis was heavily infested with sporocysts of a protozoan resembling Hepatozoon triatomae (Osimani) (Haemogregarinidae).

While collecting bugs inside houses we were impressed by the absence of known predators of triatomines. In contrast, associated with the peridomestic habitats of $T$. sordida, there was an abundance of spiders, lizards and reduviids of the species Microtomus tibialis Stichel, 1926 (Reduviidae: Microtominae). M. tibialis, which was also found in tree holes with $T$. pseudomaculata, readily killed $T$. sordida in the laboratory. Older residents of Barreiro Vermelho remarked that spiders and geckoes had formerly been common inside houses but that now only triatomines and cockroaches (Blattella germanica) were seen.

The apparent absence of spiders and of $T$, fariai inside houses could well be due to DDT residues; wall scrapings taken from four houses in May 1976 and analysed by gas-liquid chromatography in January 1977 at the Monks Wood Experimental Station (England) contained 220 to 745 (mean 505) $\mu \mathrm{g}$ of DDT per $\mathrm{g}$.

\section{Reservoir hosts}

Of the 21 households, 17 had one or more dogs and 17 had onc or more cats. Trypanosoma cruzi was detected by xenodiagnosis in five of 26 dogs $(19 \%)$ and nine of 31 cats $(29 \%)$. Ten households $(48 \%)$ had at least one infected dog or cat.

Of the 10 rats captured, all were positive for $T$. cruzi by xenodiagnosis and by haemoculture. In addition, nine of the rats also had a microscopically patent parasitaemia with $T$. lewisi. The one opossum (Didelphis albiventris) trapped in the study area was positive for $T$. cruzi by xenodiagnosis, haemoculture and direct examination of the blood but two wild cavies (Cavia apera) were negative by all examinations.

Discussion
Domestic Triatominae in western Bahia
Changes in the domestic triatomine fauna of
western Bahia, particularly along the São Francisco
and Rio Grande rivers (Fig. 1), have been relatively
well documented and it is thus possible to consider
our present findings in an historical context.
Triatoma pseudomaculata and $T$. sordida-species
not generally considered to be important vectors of
Trypanosoma cruzi to man-have been found in
settlements along the São Francisco river at least
since 1912, and early authors remarked on the

* Triatoma maculata (Erickson, 1848) in the earlier Brazilian literature of $T$. pseudomaculata Correia \& Spinola, 1964 in later papers probably refer to the same species, but opinions on their synonomy and distribution are confused (e.g. SHERLOck \& SERAFim, 1972; Galvao \& Carvalho, 1969). 
abundance of Triatoma sordida (NEIVA, 1914; Neiva \& Penna, 1916; Lutz \& Machado, 1915).

Colonization of houses along the São Francisco and Rio Grande rivers by Panstrongylus megistusa major vector of Chagas's disease in other areasappears to have occurred transiently in the middle of this century. LUTZ \& MACHADO (1915) recorded $P$. megistus along the upper reaches of the São Francisco in the State of Minas Gerais (Fig, 1), but not downstream in Bahia. ArAgão et al. (1955) did not find $P$. megistus along these rivers in an extensive survey of Bahia carried out between 1951 and 1953. By $1955, P$. megistus had become established in several areas along these rivers in Bahia (DIAS \& SEREBRENICK, 1958) but, by 1971, had been almost totally replaced there by $T$. infestans (SHERLOCK \& SERAFIM, 1972).

The recorded history of $T$. infestans in Bahia appears, at first sight, to be confusing. Because of the importance of this species as a vector of Chagas's disease, it is worth reviewing the available evidence in some detail. NeIva (1914), who considered Bahia to be among the states of Brazil with the best studied triatomine fauna, gave the distribution of $T$. infestans in Brazil as extending from the southern state of Rio Grande do Sul as far north as the state of Minas Gerais. Early records of $T$. infestans from Bahia are of doubtful validity: PINTO (1925) included $T$. infestans in the fauna of Bahia but gave no reference. He may have been influenced by LUTZ \& Machado (1915), who listed $T$. infestans in the appendix of their account of a journey down the river Sào Francisco, but comparison with the main text suggests strongly that this name was an error for $T$. sordida. ARAGÃo et al. (1955) reported $T$. infestans from the north of Bahia, but the identification of this material has been questioned (ARAGÃo et al., 1964). BUSTAMENTE (1957) recorded $T$. infestans from Minas Gerais and Goias during 1950-55, but not from Bahia. Dias \& SEREBrenick (1958) found $T$. infestans in Carinhana, on the southern border of Bahia, but not further north in the state. Between 1955 and 1964, $T$. infestans appeared as far north as the states of Alagoas and Pernambuco (Fig. 1) (LuCENA, 1959, 1965).

Comparison of the surveys of DIAS $\&$ SEREBRENICK (1958) and SHERlock \& SERAFIM (1972) shows that widespread colonization of houses by $T$. infestans in the Sào Francisco Valley region of Bahia occurred between 1956 and 1971 , by which time 23 areas in Bahia were affected (Fig. 1). At the same time, $P$. megistus disappeared from the areas colonized by $T$. infestans. In Riacho de Santana this transition occurred in 1964 (I.A.S., unpublished survey records).

With the exception of the specimens found by BARRETTO \& FERRIOLI FILHO (1964) in sylvatic habitats, $T$. infestans in Brazil has only been found in houses and the peridomestic environment. It is thought to have been dependent on man for its distribution, possibly from an original rupicoline habitat in the inter-Andean valleys of Bolivia (USINGER et al., 1966). A major factor favouring the movement of $T$. infestans into Bahia during the decade 1955-65 was probably the increasing volume of moturized road traffic between Bahia and the south: passive transport of $T$. infestans is known to have occurred in other regions and SOLER et al. (1969) give particularly striking examples.

$T$. infestans can tolerate high doses of DDT (Agosin et al., 1961) and it is possible that the use of this insecticide for malaria control may have favoured $T$. infestans by selective elimination of natural enemies of domestic triatomines (BARRETT, 1976). In Venezuela, increased infestations of houses by Rhodnius prolixus following DDT spraying have been reported by BERTI et al. (1961).

The quality of house construction in Barreiro Vermelho was in general much higher than in rural areas of endemic Chagas's disease in eastern Bahia. None the less, the presence of bug faeces on the upper halves of well-plastered walls was indicative of heavy infestations even in the best houses. Apparently $T$. infestans found adequate refuge along the tops of the walls or among roof tiles. House improvement projects have been proposed as fundamental to the successful control of domestic triatomines (e.g. DE RAADT, 1976), but the colonization of well constructed houses in Barreiro Vermelho by $T$. infestans raises the issue of whether such measures alone can prevent infestation by this species.

Sources of Trypanosoma cruzi in Riacho de Santana The high rates of $T$. cruzi infection observed in Triutoma infestans and $T$. sordida in Riacho de Santana (Table I) are in contrast to rates of less than $6^{\circ}$, recorded in previous surveys in western Bahia (ARAgão et al., 1955; Sherlock \& Serafim, 1974; Castleton et al., 1974). Moreover, Sherlock \& SERAFIM (1974) examined five $P$. megistus, $47 T$. sordida and $25 T$. infestans collected in Riacho de Santana before 1972 and found none to be infected with Trypanosoma cruzi.

In areas with stable transmission of $T$. cruzi, the proportion of bugs infected increases with the cumulative number of blood meals taken and therefore with successive instars (CORREA et al., 1952; Coura \& Petana, 1975; Minter, 1978; Torres, 1915). The fact that a higher proportion of nymphs than of adults was infected in our samples (Table II) suggests an unstable transmission pattern due to a rapid increase in the number of infective mammalian hosts shortly before the bugs were collected. (The higher infection rates in younger nymphs than in older instars also imply that the early instar nymphs feed more frequently: this has not been verified under natural conditions, but laboratory data-e.g. GoOdCHILD, 1955; SZUMLEWICZ, 1976-suggest that this is likely to be the case.) In particular, Rattus rattus probably became increasingly dependent on domestic and peridomestic sources of food and water following the failure of the maize crop and the dryness of the woodland caused by the 1975-1976 drought. In this connection, it is of interest to note that in the house with the highest proportion of infected Triatoma infestans, we were shown rat-damaged cotton seed and the route used by rats to enter the house from the woodland. We found an uninhabited rat nest in the roof of one house and, in other houses, residents said they heard rats in the roofs at night.

Although we submitted gut contents of the triatomines collected for serological identification of 
the host blood, which would have indicated the probable sources of Trypanosoma cruzi for the bugs, the results were considered unreliable because of incorrect identification of the known control blood meals included. However, Freitas et al. (1960) and BARRETTO (1968) found that blood meals from Triatoma sordida and $T$. infestans from other areas reacted with antisera against dog, cat and rodent blood. In our study, the high rate of Trypanosoma cruzi infection in bugs from a rat-infested storage box suggests that $R$. rattus was a significant source of $T$. cruzi for bugs in Riacho de Santana.

$T$. cruzi may have been introduced into the domestic environment in Riacho de Santana with infected Triatoma infestans from the south, with human carriers infected in areas of endemic Chagas's disease elsewhere or from a local enzootic cycle of transmission. The existence of two kinds of $T$. cruzi, distinguishable on the basis of their isoenzymes, circulating together in the domestic and peridomestic environments of Riacho de Santana (BARRETT et al., in press ${ }^{\star}$ ) suggests that more than one source of parasite contributed to the outbreak, and the distribution of reservoir hosts and vectors observed indicates that domestic, peridomestic and probably sylvatic cycles of transmission are now interlinked.

SHERLOCK \& SERAFIM (1974) warned that the spread of Triatoma infestans would lead to an increased prevalence of Chagas's disease in Bahia, even though most specimens examined were not infected with $T$. cruzi in most parts of the state at that time. The events in Riacho de Santana have vindicated this prediction and emphasized once again the necessity of energetic measures to combat the further spread of $T$. infestans into north-east Brazil.

\section{Acknowledgements}

This work was carried out as part of a collaborative programme in Brazil with the participation of the Nucleo de Pesquisas da Bahia of the Fundação Oswaldo Cruz, the Pan American Health Organization, the Federal University of Bahia, the Harvard School of Public Health and the London School of Hygiene and Tropical Medicine. In Riacho de Santana, we were kindly assisted by the local unit of the Superintendencia de Campanhas de Saúde Pública (SUCAM), by Mayor Dr. João Batista Dias Laranjeiras, Dr. Nilton Cardoso Fernandez, and members of the municipal staff. We were supported in the field by Sr. Tomé Silva de Oliveira and in the laboratory by Srta. Vera Lucia Menezes. This project was supported financially by the Wellcome Trust, the Pan American Health Organization and Indústria e Comércio de Mineração, S.A. (ICOMI).

\section{References}

Agosin, M., Scaramelli, N. \& Neghme, A. (1961). Intermediary carbohydrate metabolism of Triatoma infestans (Insecta: Hemiptera). I. Glycolytic and pentose phosphate pathway enzymes and the effect of DDT. Comparative Biochemistry and Physiology, 2, 143-159.

Aragão, J. M. B., Aguirre, G. H., L.eal, J. M. \& Serafim, E. (1955). Contribuição ao conhecimento

* Trans. R. Soc, trop. Med. Hyg., 74 (1). da distribuição geográfica dos triatomineos domiciliarios e seus indices de infecção natural por Schizotrypanum cruzi, no estado da Bahia. Revista Brasileira de Malariologia e Doensas Tropicais, 7, 409-421.

Aragão, M. B. (1964). Correspondência cientifica. Revista Brasileira de Malariologia e Doenças Tropicais, 16, 420-425.

Barrett, T. V. (1976). Parasites and Predators of Triatominae. In: New Approaches in American Trypanosomiasis Research. Washington: Pan American Health Organization, Scientific Publication No. 318, pp. 24-32.

Barretto, M. P. (1968). Estudos sôbre reservatórios e vectores silvestres do Trypanosoma cruzi. XXXI: Observações sôbre a associação entre reservatórios e vectores, com especial refer ência a regiâo nordeste do estado de São Paulo. Revista Brasileira de Biologia, 28, 481-494.

Barretto, M. P. \& Ferriolli Filho, P. (1964). Estudos sobre reservatórios e vectores silvestres do Trypanosoma cruzi. IV.: Infecção natural do Triatoma infestans, encontrado em ecótopos silvestres, por tripanosomo semelhante ao $T$. cruzi. Revista do Instituto de Medicina Tropical de São Paulo, 6, 219-224.

Berti, A. L., Gomez Nuñez, J. C., Guerrero, L. \& Martini, G. G. (1961). Estado actual de la enfermedad de Chagas en Venezuela. IV. Conversión de la campaña de erradicación de la malaria en profilaxis de la enfermedad de Chagas. Revista Venezolana de Sanidad y Asistencia Social, 26, 32-40.

Bustamente, F. M. (1957). Distribuição geofráfica dos transmissores da doença de Chagas no Brasil e sua relação com certos fatôres climáticos. Epidemiologia e profilaxia da enfermedade. Revista Brasileira de Malariologia e Doenças Tropicais, 9, 191-211.

Castleton, C. W., Martins, R. P. \& Viera, J. P. (1974). Levantamentos de triatomíneos domiciliares em Barreiras, Bahia. Revista Goiana de Medicina, 20, 201-207.

Correa, R. R., Oliveira, F. de \& Carvalho, P. J. (1952). Da infecção natural pelo Trypanosoma cruzi das ninfas e adultos do Triatoma infestans (Hemiptera, Reduviidae). Arquizos de Higiene $e$ Saude Pública, 17, 9-14.

Coura, J. R. \& Petana, W. B. (1975). Additional data on the epidemiology of Chagas' disease in the municipality of Caxias, Rio de Janeiro state, Brazil. Revista da Sociedade Brasileira de Medicina Tropical, 9, 83-87.

Dias, E. \& Serebrenick. S. (1958). Aspectos climáticos da distribuição dos transmissores da Doença de Chagas no Valé do Rio São Francisco. Memórias do Instituto Oswaldo Cruz, 56, 407-414.

Freitas, J. L. Pde, Siquiera, A. F. de \& Ferreira, O. A. (1960). Investigações epidemiológicas sôbre triatomíneos de hábitos domesticos e silvestres com auxilio do reação de precipitina. Revista do Instituto de Medicina Tropical de Säo Paulo, 2, 90-99.

Galvão, A. B. \& Carvalho, A. L. de M. (1969). Triatoma maculata (Erickson, 1848) uma especie ocorrente em Goias. Revista Brasileira de Malariologia e Doenças Tropicais, 21, 830-832 
Goodchild, A. J. P. (1955). Some observations on growth and egg production of the blood-sucking Reduviids, Rhodnius prolixus and Triatoma infestans. Proceedings of the Rnyal Entomological Society of London (A), 30, 137-144.

Hueck, K. (1960-1961). Die waldgeographischen Regionen und Unterregionen von Südamerika. Geographisches Taschenbuch, pp. 224-234.

Lucena, D. T. (1959). Ecologia dos triatomineos do Brasil. Revista Brasileira de Malariologia e Doenças Tropicais, 11, 577-635.

Lucena, D. T. (1965). Introdução de Triatoma infestans (Klug, 1834) em Pernambuco. Revista Brasileira de Malariologia e Doenças Tropicais, 17, 407-414.

Lutz, A. \& Machado, A. (1915). Viagem pelo Rio S. Francisco e por alguns dos seus afluentes entre Pirapora e Joazeiro. Memórias do Instituto Oswaldo Cruz, 7, 5-50.

Minter, D. M. (1978). Triatomine bugs and the household ecology of Chagas' disease. In: Medical Entomology Centenary (1977) Symposium Proceedings. Willmott, S. (Editor). London: Royal Society of Tropical Medicine and Hygiene, pp. 85-93.

Mott, K. E., Lehman, J. S., Hoff, R., Morrow, R. H., Muniz, T. M., Sherlock, I., Draper, C. C., Pugliese, C. \& Guimarães, A. C. (1976). The epidemiology and household distribution of seroreactivity to Trypanosoma cruzi in a rural community in northeast Brazil. American fournal of Tropical Medicine and Hygiene, 25, 552-562.

Neiva, A. (1914). Contribuição para o estudo dos redúvidas hematófagos. 1. Notas sôbre os redúvidas hematofagos da Bahia com a descrição de nova especie. Memórias do Instituto Oswaldo Cruz, 6, 35-39.

Neiva, A. \& Pcnna, B. (1916). Viagem cientifica pelo norte da Bahia, sud oeste de Pernambuco, sul do Piauhi e de norte a sul de Goiaz. Memórias do Instituto Oswaldo Cruz, 8, 74-224.

Pan, C. T. (1968). Cultivation of the leishmaniform stage of Trypanosoma cruzi in cell-free media at different temperatures. American Fournal of Tropical Medicine and Hygiene, 17, 823-832.

Pinto, C. F. (1925). Ensaio monographico dos reduvideos hematóphagos ou "barbeiros". Sciencia Médica, 3, 597-664, 688-718, 748-768.

Raadt, P. de (1976). Improvement of rural housing as a means of control of Chagas' disease. In: New Approaches in American Trypanosomiasis Research. Washington: Pan American Health Organization, Scientific Publication No. 318, pp. 323-325.

Sherlock, I. A. \& Serafim, E. M. (1972). Fauna Triatominae do Estado da Bahia, Brasil. 1. As espécies e distribuição geográfica. Revista da Sociedade Brasileira de Medicina Tropical, 6, 263-298.

Sherlock, I. A. \& Serafim, E. M. (1974). Fauna Triatominae do Estado da Bahia, Brasil. IV. Prevaléncia geográfica da infecção dos triatomineos por $T$. cruzi. Revista da Sociedade Brasileira de Medicina Tropical, 8, 129-142.

Soler, C. A., Sheone, H. \& Reyes, M. (1969). Problemas derivados de la reaparición de Triatoma infestans en viviendas desinsectadas y el concepto de reinfestación. Boletin Chileno de Parasitologia, 24, 83-87.

Szumlewicz, A. P. (1976). Laboratory colonies of Triatominae, biology and population dynamics. In: New Approaches in American Trypanosomiasis Research. Washington: Pan American Health Organization, Scientific Publication No. 318, pp. 63-82.

Torres, C. B. M. (1915). Alguns fatos que interessam á epidemiolojia da moléstia de Chagas. Memórias do Instituto Oswaldo Cruz, 7, 120-138.

Usinger, R. L., Wygodzinski, P. \& Ryckman, R. E. (1966). The biosystematics of Triatominae. Annual Review of Entomology, 7, 309-330.

Accepted for publication 28th March, 1979. 